Asian J. Med. Biol. Res. 2020, 6 (1), 27-37; doi: 10.3329/ajmbr.v6i1.46476

\author{
Asian Journal of \\ Medical and Biological Research \\ ISSN 2411-4472 (Print) 2412-5571 (Online) \\ www.ebupress.com/journal/ajmbr
}

\title{
Article \\ Lactobacillus xylosus isolated from butter showed potentiality to be used as probiotic and biopreservative
}

\author{
Md. Anisur Rahman ${ }^{1}$, Asma Talukder ${ }^{1}$, Shuvo Chandra Das ${ }^{1}$, Imam Hossain ${ }^{2}$, Popy Devnath ${ }^{2}$, Sutapa \\ Bhowmik $^{2}$, Mohammad Sharif Uddin ${ }^{3}$ and Md. Mijanur Rahman ${ }^{2}$ \\ ${ }^{1}$ Department of Biotechnology and Genetic Engineering, Noakhali Science and Technology University, \\ Noakhali-3814, Bangladesh \\ ${ }^{2}$ Department of Microbiology, Noakhali Science and Technology University, Noakhali -3814, Bangladesh \\ ${ }^{3}$ Department of Microbiology, University of Chittagong, Chittagong-4331, Bangladesh
}

Corresponding author: Md. Mijanur Rahman, Assistant Professor, Department of Microbiology, Noakhali Science \& Technology University (NSTU), Noakhali-3814, Bangladesh. Phone: +88 01823103818; E-mail: mijan.cu91@gmail.com

Received: 01 February 2020/Accepted: 22 March 2020/ Published: 31 March 2020

\begin{abstract}
Today, in an era of antibiotic-resistant pathogens and other looming microbial threats, the value of prevention of infection is recognized. To circumvent the indiscriminate use of antibiotics and emerging resistance to them, to reduce the use of chemical preservatives and to abate abdominal, gastrointestinal and urogenital disorders- probiotics and bacteriocins are getting paramount priority in recent times. We investigated the probiotic and bacteriocinogenic potentiality of Lactobacillus isolated from milk products. 15 lactic acid bacteria (LAB) were isolated from milk product samples using De Man Rogosa Sharpe (MRS) medium. Among them, only one (6\%) isolate showed potential antibacterial activity against Staphylococcus aureus, Escherichia coli, Salmonella typhi, Pseudomonas aeruginosa and Bacillus subtilis in agar well diffusion method. Following conventional methods, genus and species of the isolate were confirmed as Lactobacillus xylosus. The isolate exhibited growth competency at wide range of temperatures $\left(27-45^{\circ} \mathrm{C}\right), \mathrm{pH}(2-9), \mathrm{NaCl}(1-7 \%)$, bile salt $(0.5-$ $2 \%$ ) and could produce bacteriocin or BLS, thus implying its potential probiotic nature. Bacteriocins or BLS produced by Lactobacillus xylosus inhibited $E$. coli and $S$. aureus and could retain their antibacterial activity at wide range of temperatures $\left(37^{\circ} \mathrm{C}\right.$ to $\left.100^{\circ} \mathrm{C}\right)$ and $\mathrm{pH}(2-9)$ treatments. These crude bacteriocins or BLS of $5 \%$ concentration reduced the initial bacterial load of cheese and milk up to $41 \%$ and $43 \%$ respectively, after $48 \mathrm{~h}$ of preservation at room temperature. The experimental data revealed that our study isolate Lactobacillus xylosus could be used as probiotics and their bacteriocin or BLS could be used as bio-preservatives.
\end{abstract}

Keywords: probiotics; Lactobacillus xylosus; bacteriocin; lactic acid bacteria; bio-preservatives; antibacterial activity

\section{Introduction}

Modern world is becoming more and more conscious about the correlation between proper nutrition and good health. This tendency has prompted huge research on the discovery and identification of food items and food adjutants that confer special benefits upon consuming (Agrawal, 2005). Probiotics are one of the optimistic additions to this quest. Several individual researchers and organizations have so far tried to define "probiotics" of them; most widely accepted definition is that of Fuller (1989). According to him, "probiotics are live microbial food supplements that beneficially affect the host animal by improving the intestinal microbial balance" (Fuller, 1989). The Food and Agriculture Organization of the United Nation (FAO) and the World Health Organization (WHO) define probiotics as "Live microorganisms which when administered in adequate amounts confer a health benefit on the host" (FAO/WHO, 2001). Probiotics modulate our gut microbiota by 
both direct and indirect biological effects. Direct effects include adhesion to specific areas of gastrointestinal tract and exclusion of pathogens through nutrients competition. Indirect effects include production of lactic acid which decreases the $\mathrm{pH}$, production of $\mathrm{H}_{2} \mathrm{O}_{2}$ that interacts with the toxins produced by pathogens, synthesis of bacteriocins and mucins (Hu et al., 2017; Islam et al., 2016; Dinkçi et al., 2006). Upon ingestion, probiotics exert some beneficiary effects on human body, such as (i) reducing the duration of infectious and/or antibiotic associated diarrhea through influencing enteric nervous system and/or immune system to produce neuropeptides, cytokines or hormones that minimize secretion of water and electrolytes across the intestinal epithelium (Rahman et al., 2018; Andersson et al., 2001), (ii) control of lactose intolerance through delivery of microbial lactase to small intestine (Sanders, 2003), (iii) control of irritable bowel syndrome through alteration of population of intestinal microflora (Rahman et al., 2018; Sanders et al.,2003), (iv) prevention of ulcers associated with Helicobacter pylori infection through antipathogen activity (Sanders, 2003; Nami et al., 2019), (v) prevention of urinary tract infection, kidney stones and flair-ups of Chron's disease (Reid, 2005), (vi) prevention of inflammatory bowel disease through down regulation of inflammatory response (Sanders, 2003), (vii) exhibition of anti-mutagenic and anti-carcinogenic features through mutagen absorption and inhibition of carcinogen producing microflora (Sanders, 2003; Nami, 2019), (viii) increased intestinal mucosal barrier (Ahl et al., 2016).

Lactic acid bacteria (LAB) are a major broad group of probiotic bacteria. LAB are gram positive, non-sporing, catalase negative, cocci-shaped, usually non-motile organisms that are devoid of cytochrome $\mathrm{C}$ and are nonaerobic, but are aerotolerant and acid tolerant which produce lactic acid as the major end product (Agrawal, 2005; Nami et al., 2019; Chowdhury et al., 2012). These microbes are ubiquitous in nature and are indigenous inhabitants of the human gastrointestinal tract, vagina and human skin, but are also found in soil, water, vegetables products, meats, fermented and cooked meat and dairy products (Andersson et al., 2001; Li et al., 2018). LAB deploy strong antagonistic activity against pathogenic, non-pathogenic and spoilage organisms in fermented milk, foods and beverages (Gilliland et al., 1975) and demonstrate antimutagenic properties through reducing the activity of $\beta$-glucornidase, nitro reductase and azoreductase which convert precarcinogen into its active form (Guarner et al., 2003).

A major group of LAB, known as Lactobacillus species, are most widely utilized group of microorganisms as probiotics due to their "Generally recognized as safe" (GRAS) status (Islam et al., 2016). Lactobacillus spp. are omnipresent in nature, especially in the human gut, particularly in the small intestine as this portion of GIT provides anaerobic condition, sugars as a carbon source, a range of minor nutrients to support their growth and sustainability (Rahman et al., 2018). Lactobacillus spp. have been proved to be effective in allergic children (Martínez-Cañavate et al., 2009), preventing vasculopathy in obesity (Toral et al., 2014), reducing the risk of necrotizing enterocolitis in low birth weight premature babies (Hoyos et al., 1999).

Having a moderate $\mathrm{pH}$ (6.4-6.6), adequate nutrients, high water contents, milk provides an excellent environment for microbial growth and fermented milk could be a valuable source of autochthonous Lactic Acid Bacteria (LAB) (El Soda et al., 2003). The dietary and therapeutic values of milk products are determined by presence of probiotic microbes (Boor et al., 2001). Lactobacillus and Streptococcus spp. are most commonly used probiotics in commercial fermented and non- fermented milk product now a days (Chowdhury et al., 2012). Some strains even contribute to the preservation of fermented milk and foods by producing bacteriocins (Ten Brink et al., 1994). Bacteriocins are ribosomally synthesized antimicrobial peptides that exhibit bactericidal activity against closely related organisms (Bromberg et al., 2004). Since bacteriocin producing LAB are mostly isolated from dairy foods and meat products, these proteinaceous substances thus have been consumed for a long time. So, considering all the facts discussed above, our present study focused on isolation of Lactobacillus spp. from dairy products and in in-vitro evaluation of their probiotic and bacteriocinogenic potentiality.

\section{Methods and Materials}

\subsection{Sample collection, isolation and purification of Lactobacillus}

Multiple sets of milk products samples (Butter and cheese) were collected from local shops of Chittagong area in Bangladesh. For isolation of Lactobacillus, serial dilution $\left(10^{-1}\right.$ to $\left.10^{-6}\right)$ agar plate technique was used. Lactobacillus was purified by streak plate method on De Man Rogosa Sharpe (MRS) agar.

\subsection{Test microorganisms}

The target pathogenic organisms used in this study were Staphylococcus aureus ATCC25923, Bacillus subtilis IFSTIM22, Pseudomonas aeruginosa CRL (ICDDR, B), E. coli ATCC25922, Salmonella typhii AE14296. The test microorganisms were standardized by using 0.5 McFarland standard. A 0.5 McFarland gives approximate 
cell density of $1.5 \times 10^{8} \mathrm{CFU} / \mathrm{mL}$, having absorbance of 0.132 at wavelength of $600 \mathrm{~nm}$ (Andrews et al., 2001). We used this standardization technique for all the necessary steps of this study.

\subsection{Screening of isolated Lactobacillus for antibacterial activity}

MRS broth was used for antimicrobial metabolite production from Lactobacillus. $200 \mathrm{~mL}$ of MRS broth was autoclaved at $121^{\circ} \mathrm{C}$ for 15 minutes and inoculated with the colonies of a Lactobacillus isolate and incubated at $37{ }^{\circ} \mathrm{C}$ for 2-3 days under stationary condition. Then it was centrifuged (Model 6930, Kubota, Japan) at 9000 rpm for 15 minutes at $4{ }^{\circ} \mathrm{C}$. The supernatant was then filtered through Whatman No. 1 filter paper to remove residual cells. Petri-plates were prepared by pouring sterile molten Muellar Hinton medium and allowed it to solidify. A hundred microliters of each standardized test microorganisms were spread on agar plates. Two wells (each $7 \mathrm{~mm}$ in diameter) made into agar plates with sterile borer. The wells were loaded with $100 \mu \mathrm{L}$ of filtered LAB culture supernatant and $100 \mu \mathrm{L}$ sterile broth. Plates were incubated at $37{ }^{\circ} \mathrm{C}$ for 24 hours. After incubation, diameter of zone of inhibition was observed and measured (Pundir et al., 2013).

\subsection{Identification of Lactobacillus isolates}

Lactobacillus species were identified based on their morphological characteristics including size and shape of the organism, arrangement of the cells, presence or absence of the spores, regular or irregular forms, acid fastness, gram reaction etc.; cultural and physiological characteristics including $\mathrm{H}_{2} \mathrm{~S}$ production, nitrate reduction, deep glucose agar test, fermentation of different carbohydrates etc. All these characteristics were then compared with the standard description of "Bergey's Manual of Determinative Bacteriology", 8th edition (Buchanan and Gibbons, 1974).

\subsection{Determination of probiotic efficiency of Lactobacillus xylosus} 2.5.1. pH tolerance and temperature sensitivity

The Lactobacillus cultures were inoculated into sterile MRS broth tubes of varying $\mathrm{pH}$, i.e., 2, 4, 7 and 9 and incubated at $37{ }^{\circ} \mathrm{C}$ for $24-48$ hours. Another set of inoculated MRS broth was grown at varying temperatures, i.e., 27, 37, and $45{ }^{\circ} \mathrm{C}$ for $24-48$ hours. The absorbance of MRS broths were taken at $600 \mathrm{~nm}$ by a spectrophotometer (Model T60U, pg instruments, UK) to measure microbial load (Rahman et al., 2019).

\subsubsection{Bile salt and $\mathrm{NaCl}$ tolerance}

The MRS broth media with varying concentrations of bile salt $(0.5,1.0$ and $2.0 \%)$ and $\mathrm{NaCl}(1,3$ and $7 \%)$ were inoculated separately with each Lactobacillus culture and incubated at $37^{\circ} \mathrm{C}$ for 48 hours. Then the absorbance of MRS broths were taken at $600 \mathrm{~nm}$ by a spectrophotometer for measuring microbial load (Rahman et al., 2018).

\subsubsection{Lactose utilization}

The acid production by Lactobacillus cultures was detected by observing the change in color of the medium. Sterilized fermentation medium (Peptone $10 \mathrm{~g}, \mathrm{NaCl} 15 \mathrm{~g}$, phenol red $0.018 \mathrm{~g}$, lactose $5 \mathrm{~g}$, for $1 \mathrm{~L}$ distilled water and final $\mathrm{pH}$ 7.0) was inoculated with Lactobacillus cultures and incubated at $37{ }^{\circ} \mathrm{C}$ for $24-48 \mathrm{~h}$. Change in color from red to yellow indicates the production of acid (Ahmed and Kanwal, 2004).

\subsubsection{Antibiotic susceptibility test}

The antibiotic susceptibility of Lactobacillus was assessed by using Kirby-Bauer discs diffusion method on MRS agar plates. The used antibiotics were penicillin g (10 IU), chloramphenicol (30 $\mu \mathrm{g})$, erythromycin (15 $\mu \mathrm{g})$, cefixime $(5 \mu \mathrm{g})$, cephradine $(30 \mu \mathrm{g})$, streptomycin $(10 \mu \mathrm{g})$ and rifamycin $(5 \mu \mathrm{g})$ (Rahman et al., 2019).

\subsubsection{Determination of bacteriocin production capability of the Lactobacillus xylosus}

This experiment has been carried out according to the method described by Yang et al., 2012 (Yang et al., 2012). One milliliter of frozen Lactobacillus isolate was cultured 24 hours in $20 \mathrm{~mL}$ MRS broth. Then $1 \mathrm{~mL}$ culture was sub-cultured $24 \mathrm{~h}$ in $20 \mathrm{~mL}$ MRS broth. Cells were removed by centrifuging at $9000 \mathrm{rpm}$ for 15 minutes. The supernatant was filtered through a sterile Whatman No. 1 filter paper and $100 \mu \mathrm{L}$ of the $\mathrm{pH}$ unadjusted aliquot of cell free supernatant (CFS) was added to the first well. The remaining CFS was adjusted to $\mathrm{pH} 6.0$ with $1 \mathrm{M} / 1 \mathrm{~N} \mathrm{NaOH}$ in order to rule out possible inhibitory effects due to organic acids. $100 \mu \mathrm{L}$ of the $\mathrm{pH}$ adjusted CFS was filtered and added to the second well. The neutralized CFS was then treated with $1 \mathrm{mg} / \mathrm{mL}$ of catalase (Merck KGa A, Germany) at $25{ }^{\circ} \mathrm{C}$ for $30 \mathrm{~min}$ to eliminate the possible inhibitory action of $\mathrm{H}_{2} \mathrm{O}_{2}$ and filtered. Then $10 \mu \mathrm{L}$ catalase treated CFS was placed in the third well. If inhibition zone were found in the 
third well, the isolates were able to produce bacteriocin or BLS. To confirm the production of a proteinaceous compound, CFS displaying antimicrobial production after acid neutralization and $\mathrm{H}_{2} \mathrm{O}_{2}$ elimination were treated with $1 \mathrm{mg} / \mathrm{mL}$ of proteolytic enzymes including papain and trypsin (Sigma-Aldrich Corporation, USA). 5ml of bacteriocin was taken in test-tubes and treated with papain/trypsin $(1 \mathrm{mg} / \mathrm{mL})$ at $\mathrm{pH}$ 7. The test tubes with and without the enzyme (control) were incubated at $37{ }^{\circ} \mathrm{C}$ for $2 \mathrm{~h}$ and then heated at $100{ }^{\circ} \mathrm{C}$ for 3 min to denature the enzyme. Both the control and samples were assayed for antimicrobial activity by using agar well diffusion method (Rahman et al., 2019).

\subsubsection{Heat stability and effect of $\mathrm{pH}$ on the crude Bacteriocin or BLS}

Five millilitres of crude bacteriocin in different test-tubes was taken and then heated at $37,45,60$, and $100^{\circ} \mathrm{C}$ for 15 minutes respectively. In another set, $5 \mathrm{~mL}$ of crude bacteriocin or BLS was taken in test-tubes and the $\mathrm{pH}$ of the contents were adjusted to $\mathrm{pH} \mathrm{2,4,7}$ and 9 separately, using either diluted $\mathrm{NaOH}$ or $\mathrm{HCl}$ and allowed to stand at room temperature for 2 hours. The heat and $\mathrm{pH}$ treated crude bacteriocin or BLS samples were then assayed for antimicrobial activity. Agar well diffusion method was used and $100 \mu \mathrm{L}$ of sample was added in each well (Nithya et al., 2012).

\subsubsection{Bio-preservative efficiency of the crude Bacteriocin or BLS}

Milk and cheese samples were added with 5\% of crude bacteriocin or BLS of L. xylosus MB1 separately and kept at room temperature for 48 hours. The controls were maintained without adding crude bacteriocin or BLS. After 24 hours of incubation, the samples (both test and control) were serially diluted up to $10^{-6}$ and the plates were incubated at $37^{\circ} \mathrm{C}$ for 24 hours. The colony count was recorded and compared with the control (Joshi et al., 2006).

\section{Results and Discussion}

The present study aimed to isolate Lactobacillus spp. from milk products samples (butter and cheese), evaluation of their probiotic potentiality and assessment of their bacteriocin or bacteriocin-like substance (BLS) production capability. The Lactobacillus isolates were primarily screened for their antibacterial activity as probiotic Lactobacillus should be good antimicrobial producer.

\subsection{Isolation, screening based on their antibacterial activity and identification of Lactobacillus}

A total of 15 Lactobacillus were isolated from the milk products samples using MRS medium. Among them, only 3 isolates $(20 \%)$ showed potential antibacterial activity against at least three test organisms and only one $(6 \%)$ isolate displayed antibacterial potentiality against all the five test microorganisms. This isolate, labelled as MB1, showed antibacterial activity against $S$. aureus $(15 \mathrm{~mm})$, E. coli $(11 \mathrm{~mm})$, S. Typhi $(13 \mathrm{~mm}), P$. aeruginosa $(15 \mathrm{~mm})$ and $B$. subtilis $(14 \mathrm{~mm})$. The genus and species of the isolate (MB1) were confirmed by conventional methods using cultural, morphological characteristics and biochemical reactions as described in "Bergey's Manual of Determinative Bacteriology", $8^{\text {th }}$ edition (Buchanan et al., 1974) (Table 1). Finally, having identified the isolate as Lactobacillus xylosus, we approached for further experiments.

\subsection{Evaluation of probiotic potentiality of $L$. xylosus MB1}

\subsection{1. $\mathrm{pH}$ tolerance, temperature sensitivity, bile salt and $\mathrm{NaCl}$ tolerance}

The growth of L. xylosus MB1 accelerated with the gradual increase of $\mathrm{pH}(2-7)$ and reached its optimum level at $\mathrm{pH} 7$ and then again dropped with an increased $\mathrm{pH}$ (Figure 1a). Lactic acid bacteria must pass through the gastric juice of stomach having an acidic environment (lower $\mathrm{pH}$ ), which destroys most of the microorganisms ingested (Charteris et al., 1998). Therefore, resistance to low $\mathrm{pH}$ is an important selection criterion for the probiotic microorganisms. Other studies also ensured that, although the growth rate of Lactobacillus strains dropped after being exposed to $\mathrm{pH}$ values of 2.5-4.0, yet they can continue to survive. Moreover, their survival in the media resembling the stomach environment (having physiological $\mathrm{pH}$ of 2-3) was found to be variable and strain dependent. However, this survival rate was reported to be of approximately $85 \%$, which is very significant for the probiotic bacteria (Belicová et al., 2013).

An efficient probiotic Lactobacillus must be capable of surviving at wide range of $\mathrm{pH}$ and temperature, tolerating various concentrations of bile salt and $\mathrm{NaCl}$, utilizing lactose and resistance against several antibiotics. The study isolate Lactobacillus xylosus MB1 was able to tolerate a wide range of temperatures (27$45{ }^{\circ} \mathrm{C}$ ), but the best growth was found at $37{ }^{\circ} \mathrm{C}$ (Figure 1b). This value was chosen to mimic the internal body temperature and to determine whether the Lactobacillus were able to grow and survive within the human gut, an essential character of probiotics to be beneficiary for human health (Rahman et al., 2019). 
At the same time the organism should resist the bile salt in the small intestine and should adhere to the intestinal walls for its effectiveness (Agrawal, 2005). This will help Lactobacilli to colonize the intestinal environment and balance the intestinal microflora (Tambekar and Bhutada 2010). Our study isolate was able to withstand $0.5-2 \%$ concentration of bile salt in vitro growth media (Figure 1c) whereas the optimum growth was found at $0.5 \%$ concentration.

$\mathrm{NaCl}$ acts as an inhibitory compound that may muffle the growth of certain types of bacteria (Hoque et al., 2010). The current L. xylosus MB1 strain was able to grow well at $1-7 \%$ of $\mathrm{NaCl}$ concentrations and its best growth was found with $7 \% \mathrm{NaCl}$ (Figure 1d). The experimental results of our present study are in accordance with some previous findings (Pundir et al., 2013; Rahman et al., 2019).

\subsubsection{Lactose utilization and antibiotic susceptibility}

Our present study isolate MB1 could utilize lactose in vitro growth medium. Lactose is the predominant carbohydrate in milk. Insufficient $\beta$-galactosidase activity in the small bowel mucosa of newborn children perturbs the absorption of lactose from breast milk (Andersson et al., 2001) and causes lactose intolerance. This also happens in adult people who cannot metabolize lactose due to lack of this essential enzyme. In both the cases, through its passage from the small intestine, lactose is converted to gas and acid in the large intestine by the colonial microflora and the respective individuals suffer from symptomatic abdominal pain, cramping and diarrhea (Rahman et al., 2019). In these cases, addition of certain starter cultures with specific lactic acid bacteria to milk products allows the lactose digestibility and absorption in lactose intolerant people without the usual rise of breath hydrogen or associated symptoms (Pundir et al., 2013). So, fermented dairy products are being produced using specially selected strains of Lactobacillus as starter cultures which are playing significant role in infant nutrition (Dinkçi et al., 2006).

A small-scale antibiotic susceptibility test revealed that Lactobacillus xylosus MB1 is sensitive to penicillin G, chloramphenicol, erythromycin, cefixime, chephradine, streptomycin and rifamycin. Such kind of susceptibility to a wide range of antibiotics suggests that introduction of this Lactobacillus spp. in order to replenish the microbial flora in patients undergoing antibiotic therapy would not be feasible. Rather it could be used in fermented milk products as a form of preventive therapeutic approach to maintain a good balance of commensal gut microbiota as we have earlier proved its antibacterial potentiality.

\subsubsection{Determination of bacteriocin or BLS production capability of $L$. xylosus MB1}

To determine the bacteriocin or BLS production capability of L. xylosus MB1, its cell free supernatant (CFS) has been neutralized with $\mathrm{NaOH}$ to rule out the possible antimicrobial activity of organic acids and subsequently treated with catalase enzyme for reducing antimicrobial effect of $\mathrm{H}_{2} \mathrm{O}_{2}$ (Table 2; Figure 2).

If the CFS of Lactobacillus xylosus MB1 can exert the antimicrobial effects on selected test organisms after being acid neutralized and catalase treated, then the isolate may be considered as bacteriocin or BLS producer (Yang et al., 2012). Same test pathogens, which were previously used to determine the antibacterial potentiality of the current study isolate, are also employed here to ascertain whether it could produce bacteriocin or BLS. We found that our study isolate produces crude bacteriocin or BLS which has antibacterial activity against $E$. coli and S. aureus (Table 2). After treating with proteolytic enzymes papain and trypsin, the crude bacteriocin or BLS of our study isolate lost its antibacterial activity, demonstrating the proteinaceous nature of this crude substance (Figure 3). One previous study implied that many of the bactericidal agents, synthesized by lactic acid bacteria (LAB) and varying in their spectra of activity, are bacteriocins and proteinaceous in nature (Fricourt $e t$ al., 1994). Other studies also displayed that Lactobacillus spp. could produce bacteriocins which are active against E. coli and $S$. aureus, thus further supporting the findings of our present study (Rahman et al., 2018; Rahman et al., 2019).

\subsubsection{Effect of temperature and $\mathrm{pH}$ on the antibacterial activity of the crude bacteriocin or BLS produced by $L$. xylosus MB1}

The crude bacteriocin or BLS of L. xylosus MB1 retained its antibacterial activity at wide range of temperature $\left(37^{\circ} \mathrm{C}\right.$ to $100^{\circ} \mathrm{C}$ for 15 minutes) and $\mathrm{pH}(2-9$ for 2 hours) (Figure 4$)$. Using both parameters, we found the crude bacteriocin or BLS was active against $E$. coli and $S$. aureus among the five test organisms that we have employed earlier in the current study. Maximum antibacterial activity was observed against both $E$. coli and $S$. aureus after $37^{\circ} \mathrm{C}$ heat treatment. But in case of $\mathrm{pH}$ treatment, the results differed in E. coli and S. aureus. Maximum antibacterial activity was noted against $E$. coli at $\mathrm{pH} 4$ and $S$. aureus at $\mathrm{pH} 2$ respectively. Rahman $e t$ al., (2019) investigated the antibacterial properties of $L$. plantarum and $L$. delbrueckii isolated from vegetables. These strains produced bacteriocins or BLS against E. coli, S. aureus and S. typhi and were found to tolerate the 
same range of temperature $\left(37^{\circ} \mathrm{C}-100^{\circ} \mathrm{C}\right)$ and $\mathrm{pH}(2-9)$ like this present study. In addition, bacteriocins or BLS produced by both Lactobacillus spp. exhibited highest antibacterial activity at $37^{\circ} \mathrm{C}$ temperature, whereas antibacterial effects against $E$. coli and $S$. aureus from bacteriocins produced by $L$. plantarum and $L$. delbrueckii were found to be maximum at $\mathrm{pH} 4$ and $\mathrm{pH} 2$ respectively (Rahman et al., 2019). These findings are exactly in accordance with the results of our current study. Other studies also revealed that bacteriocins produced by Lactobacillus spp. were proteinaceous in nature and could endure $\mathrm{pH} 3-9$ and $37-100^{\circ} \mathrm{C}$ heat treatment (Jayachitra and Ramanathan, 2012; Udhayashree et al., 2012). Another study reported that bacteriocin produced by Lactobacillus spp. could even stand $100^{\circ} \mathrm{C}$ for 30 minutes, indicating that the bacteriocin is relatively resistant to heat, though inactivation occurred after $60 \mathrm{~min}$ at $100^{\circ} \mathrm{C}$ or after autoclaving at $121^{\circ} \mathrm{C}$ for $5 \mathrm{~min}$ (Boris et al., 2001). The heat stability of the crude bacteriocin or BLS pledges an advantage for potential use as bio-preservatives in combination with thermal processing to preserve food products (Rahman, 2019).

\subsubsection{Bio-preservative efficiency of the crude bacteriocin or BLS}

We observed that $5 \%$ crude bacteriocin or BLS of our study isolate could decrease microbial load remarkably in the milk and cheese samples after 48 hours of preservation at room temperature (Table 3). The 5\% crude bacteriocin or BLS of Lactobacillus xylosus MB1 decreased $41 \%$ of initial microbial load in cheese after treatment at room temperatures for 48 hours. In case of milk, crude bacteriocin or BLS of Lactobacillus xylosus MB1 decreased $43 \%$ of initial microbial load.

This very experimental data indicates that crude bacteriocin or BLS of Lactobacillus xylosus MB1 could possibly be used in the preservation of milk and milk products after further purification and ensuring that it would not be toxic, cause hypersensitivity or any other side effects to the human health. Previous researchers used 5\% crude bacteriocin of L. fermentum to preserve milk and mushroom and got satisfactory results (Nithya et al., 2012). Another study showed that BLS of Lactobacillus spp. isolated from ovine cheese exhibited antimicrobial activity against Listeria monocytogenes (Nespolo and Brandelli, 2010). Likewise, our examined bacteriocin or BLS also substantially reduced bacterial colony count when applied on cheese samples. Biopreservation of cheese is very important from commercial and therapeutic perspective because cheese has a higher $\mathrm{pH}$ than yogurt and fermented milk and hence can support survival of probiotic bacteria for a longer duration (Gardiner et al., 1998). However, bio-preservation of milk is never less valuable because recently specific starter cultures using specially selected strains of Lactobacillus are being used in the production of fermented dairy products (Dinkçi et al., 2006). Bacteriocin or BLS produced by our study isolate significantly mitigated bacterial colony count when applied on milk samples too, thus strengthening its candidature as an efficient bio-preservative in dairy industry. Bio-preservatives can be an effective alternative to chemical preservatives because excessive use of chemical preservatives may have deteriorative effects on human health (Rahman et al., 2019). Here, bacteriocins can play a major role. Most of the bacteriocins kill the susceptible bacteria by inducing permeabilization and pore formation on the cytoplasmic membrane or by interactions with essential enzymes. Because bacteriocins are degraded by the proteolytic enzymes of the gastrointestinal tract and seem to be nontoxic and non-antigenic to animals and humans, they can be utilized to improve the safety and shelf-life of many food products (Dinev et al., 2018).

Our study isolate Lactobacillus xylosus MB1 passed the in-vitro assessments for probiotic potentiality and showed tolerance to a wide range of $\mathrm{pH}$, temperature, bile salt and $\mathrm{NaCl}$ concentration. This isolate is also capable of producing bacteriocins or bacteriocin like substances (BLS) which are competent to sustain at different temperature and $\mathrm{pH}$ levels and exert their antibacterial activity. The bacteriocins or BLS also proved their efficiency in bio-preservation of milk and cheese samples. All these evidences obviously suggest Lactobacillus xylosus MB1 to be a prospective candidate for probiotic bacteria. Probiotic lactic acid bacteria (LAB) have protective effects on human health including boosting of the immune system, inhibition of the growth of pathogens, prevention of diarrhea from various causes, prevention of colorectal cancer, reduction of the risk of inflammatory bowel movements, improvement of digestion of proteins and fats, synthesis of vitamins and detoxification and protection from toxins (Chowdhury and Ferdouse, 2012). Based on the beneficiary effects and more secured aspects of probiotic therapy than pharmaceutical agents (Bengmark, 2002) current study isolate Lactobacillus xylosus MB1 can be used as probiotics because there are historical data supporting the safety of lactobacilli for human use (Adams and Marteau, 1995). 
Table 1. Morphological, cultural and biochemical characteristics of $L$. xylosus MB1.

\begin{tabular}{|c|c|}
\hline Parameters & L. xylosus MB1 \\
\hline \multicolumn{2}{|l|}{ Colony characteristics } \\
\hline Form & Circular \\
\hline Elevation & Raised \\
\hline Margin & Entire \\
\hline Surface & Rough (Dry) \\
\hline Color & Off-white \\
\hline Slant Character & Filiform \\
\hline Broth Character & Turbid growth with sediment \\
\hline Microscopic Observation (vegetative cell) & $\begin{array}{l}\text { Short rod, single or diplobacilli, } 2.93-3.51 \mu \mathrm{m} \text { in length } \\
\text { and } 1.56-1.95 \mu \mathrm{m} \text { in width }\end{array}$ \\
\hline Gram staining & Gram positive \\
\hline Spore staining & Non spore former \\
\hline Acid fast staining & Non-acid fast \\
\hline Motility test & Non motile \\
\hline Indole test & Negative \\
\hline Methyl Red (M.R) test & Negative \\
\hline Voges Proskauer (V.P) test & Negative \\
\hline Deep glucose agar test & Strict aerobes \\
\hline Glucose broth & Turbid \\
\hline Growth in synthetic media & Turbid \\
\hline Growth in inorganic salt & No growth \\
\hline $\mathrm{H}_{2} \mathrm{~S}$ production test & Positive \\
\hline Urease test & Negative \\
\hline Nitrate reduction test & Positive \\
\hline Citrate utilization test & Turbid with flocculent \\
\hline Catalase activity & Negative \\
\hline Starch hydrolysis & Negative \\
\hline Casein hydrolysis & Negative \\
\hline Egg albumin test & Negative \\
\hline Gelatin liquefication & Negative \\
\hline \multicolumn{2}{|l|}{ Fermentation test } \\
\hline Acid production without gas formation & Galactose, Sucrose and Inulin \\
\hline Alkali production without gas formation & Maltose, Mannitol and Xylose \\
\hline No change & Glucose, Fructose, Rhamnose, Raffinose and Starch \\
\hline
\end{tabular}

Table 2. Determination of Bacteriocin/BLS production by $L$. xylosus MB1 after eliminating antibacterial effect of acids and $\mathrm{H}_{2} \mathrm{O}_{2}$ (diameter of zone of inhibition in $\mathrm{mm}$ ).

\begin{tabular}{lllll}
\hline Test organisms & Raw CFS & CFS adjusted at pH 6 & $\begin{array}{l}\text { pH adjusted CFS after catalase } \\
\text { treatment }\end{array}$ \\
\hline E. coli & 26 & 24 & 24 & \\
S. typhii & 16 & - & - & \\
B. subtilis & 23 & 7 & - & \\
P. aeruginosa & 17 & - & - & \\
S. aureus & 23 & 22 & 22 & \\
\hline
\end{tabular}

Note: - = Do not show antimicrobial activity against respected pathogen

Table 3. Bio-preservative efficiency test of the crude bacteriocin or BLS on milk and cheese samples.

\begin{tabular}{lllll}
\hline \multirow{3}{*}{ Samples } & \multicolumn{4}{c}{ Total count of bacteria (CFU/mL) } \\
\cline { 2 - 5 } & $\begin{array}{l}\text { Control } \\
\text { bacteriocin/BLS) }\end{array}$ & (without & crude & $\begin{array}{l}\text { Test (with crude bacteriocin/ BLS } \\
\text { produced by } \text { L. xylosus) }\end{array}$ \\
\hline Cheese & $11.6 \times 10^{6}$ & $4.8 \times 10^{6}$ & \\
Milk & $12.1 \times 10^{6}$ & $5.3 \times 10^{6}$ & \\
\hline
\end{tabular}



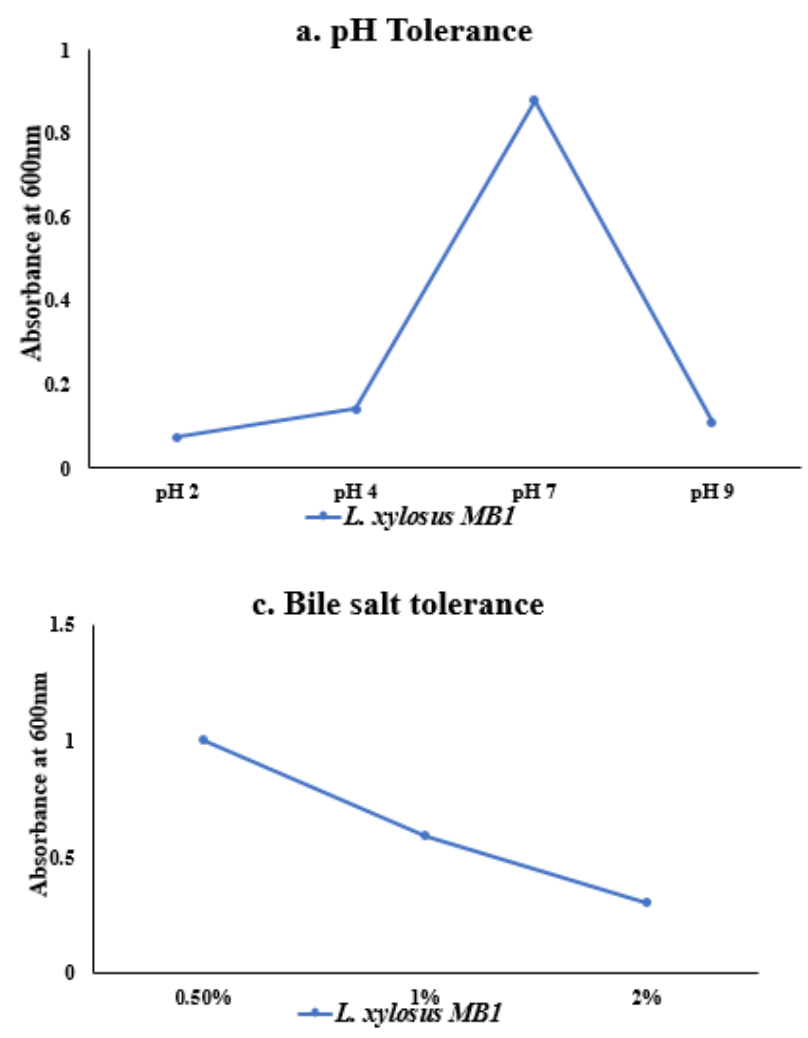

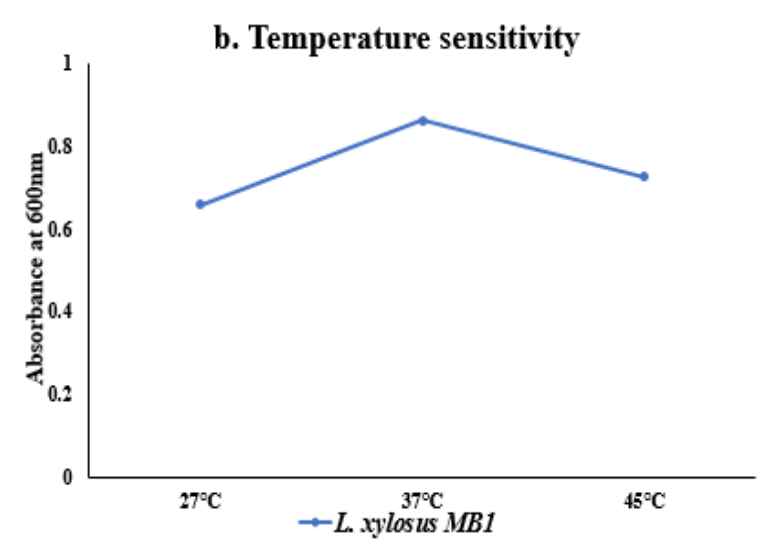

d. NaCl tolerance

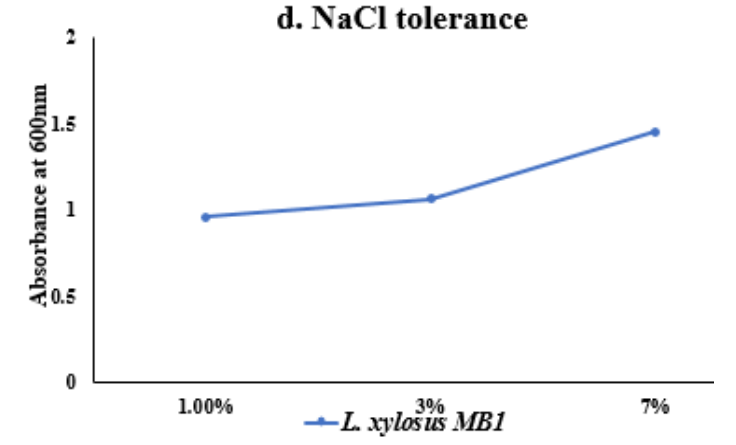

Figure 1. Lactobacillus xylosus MB1 can tolerate a wide range of (a) $\mathrm{pH}(2-9)$, (b) temperature $\left(27-45^{\circ} \mathrm{C}\right)$, (c) bile salt (0.5-2\%) and (d) $\mathrm{NaCl}(1-7 \%)$.

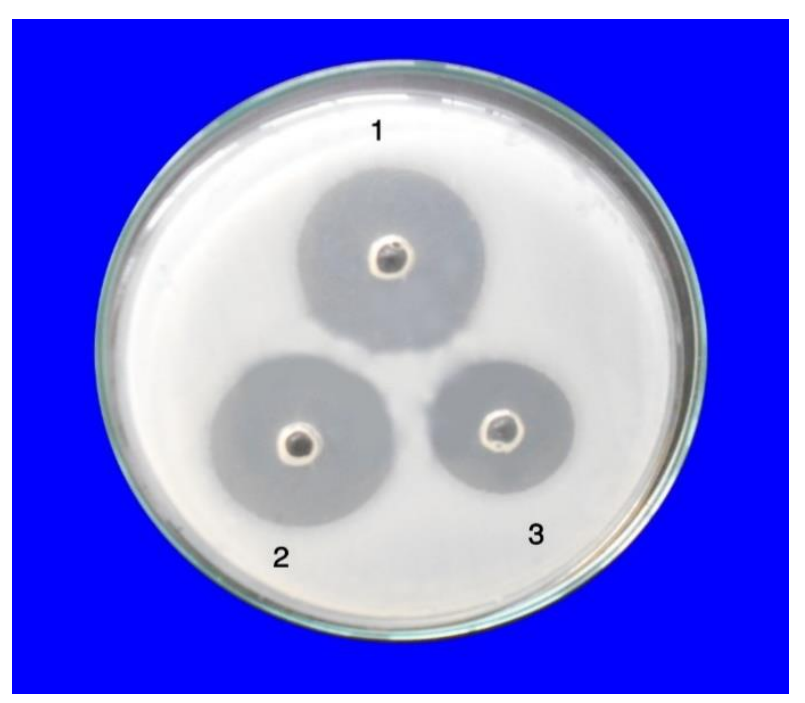

Figure 2. Activity of bacteriocin/BLS produced by the isolate $L$. xylosus MB1 against $S$. aureus. 


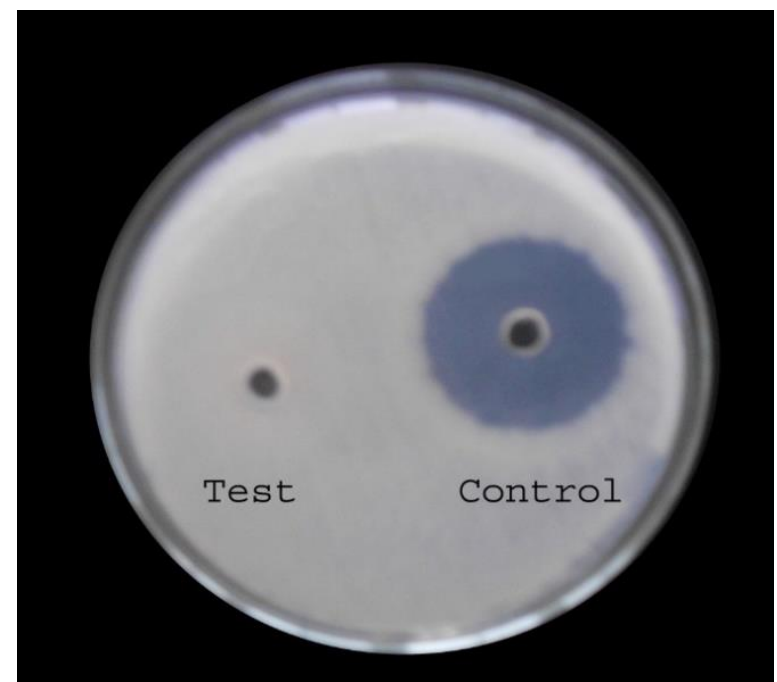

Figure 3. Effect of Trypsin on the antimicrobial activity of the crude bacteriocin/BLS produced by the isolate L. xylosus MB1 (Indicator: S. aureus).
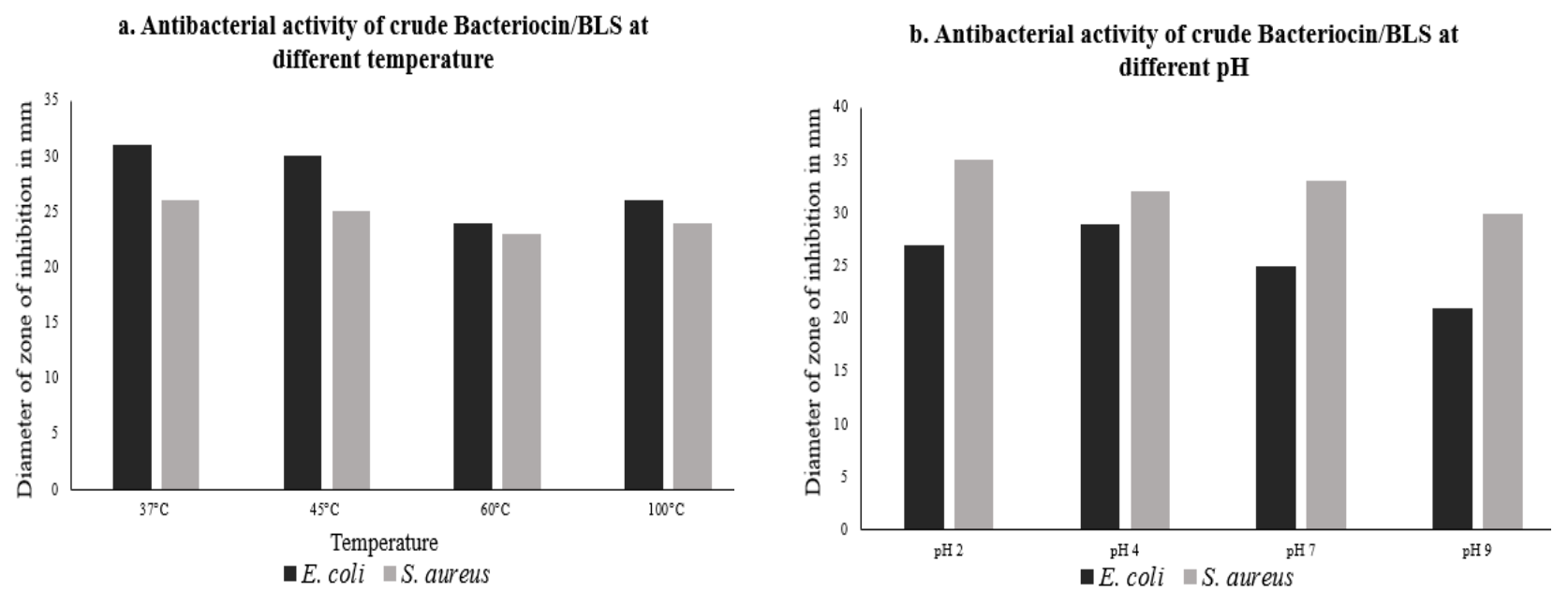

Figure 4. Antibacterial activity of crude bacteriocin or BLS produced by Lactobacillus xylosus MB1 after treatment at wide range of (a) temperature $\left(37^{\circ} \mathrm{C}-100^{\circ} \mathrm{C}\right)$ and (b) $\mathrm{pH}(2-9)$.

\section{Conclusions}

Based on experimental data and empirical observations from this study, it could be stated that our isolated Lactobacillus xylosus MB1 and its crude bacteriocin and BLS has tremendous potentiality to be used as probiotics and bio-preservatives after successfully passing through other relevant in-vitro and in-vivo tests and experiments.

\section{Conflict of interest}

None to declare.

\section{References}

Adams MR and P Marteau, 1995. On the safety of lactic acid bacteria from food. Int. J. Food Microbiol., 27: 263.

Agrawal R, 2005. Probiotics: an emerging food supplement with health benefits. Food Biotech., 19: 227-246.

Ahl D, H Liu, O Schreiber, S Roos, M Phillipson and L Holm, 2016. Lactobacillus reuteri increases mucus thickness and ameliorates dextran sulphate sodium-induced colitis in mice. Acta Physiologica, 217: 300-310.

Ahmed T and R Kanwal, 2004. Biochemical characteristics of lactic acid producing bacteria and preparation of camel milk cheese by using starter culture. Pak. Vet. J., 24: 87-91. 
Andersson H, NG Asp, A Bruc, S Roos, T Wadström and AE Wold, 2001. Health effects of probiotics and prebiotics A literature review on human studies. Näringsforskning, 45: 58-75.

Andrews JM, 2001. Determination of minimum inhibitory concentrations. J. Antimicrob., 48: 5-16.

Belicová A, M Mikulášová, and R Dušinský, 2013. Probiotic potential and safety properties of Lactobacillus plantarum from Slovak Bryndza cheese. J. BioMed Res. Int., 2013

Bengmark S, 2002. Gut microbial ecology in critical illness: is there a role for prebiotics, probiotics, and synbiotics? Curr Opin Crit Care, 8: 145-151.

Boor KJ, 2001. ADSA foundation scholar award fluid dairy product quality and safety: looking to the future. Int. J. Dairy Sci., 84: 1-11.

Boris S, R Jiménez-Díaz, JL Caso and C Barbes, 2001. Partial characterization of a bacteriocin produced by Lactobacillus delbrueckii subsp. lactis UO004, an intestinal isolate with probiotic potential. J. Appl. Microbial., 91: 328-333.

Bromberg R, I Moreno, CL Zaganini, RR Delboni and JD Oliveira, 2004. Isolation of bacteriocin-producing lactic acid bacteria from meat and meat products and its spectrum of inhibitory activity. Braz. J. Microbiol., 35: 137-144.

Buchanan RE and NE Gibbons, 1974. Bergey's Manual of Determinative. Bacteriology, 8th ed., Williams and Wilkins, Baltimore, 1268.

Charteris WP, PM Kelly, L Morelli and JK Collins, 1998. Antibiotic susceptibility of potentially probiotic Lactobacillus species. J. Food Prot., 61: 1636-1643.

Chowdhury $\mathrm{T}$ and $\mathrm{J}$ Ferdouse, 2012. Isolation, characterization and antimicrobial activity of lactic acid bacteria from local milk and milk products. Bangladesh J. Microbiol., 29: 76-82.

Dinev T, G Beev, M Tzanova, S Denev, D Dermendzhieva and A Stoyanova, 2018. Antimicrobial activity of Lactobacillus plantarum against pathogenic and food spoilage microorganisms: a review. Bulg. J. Vet. Med, 21(3).

Dinkçi N, G Ünal, S Akalin and S Gönç, 2006. The importance of probiotics in pediatrics. Pak. J. Nutr, 5: 608611.

El-Soda M, N Ahmed, N Omran, G Osman and A Morsi, 2003. Isolation, identification and selection of lactic acid bacteria cultures for cheesemaking. Emir. J. Food Agr., 15: 51-71.

FAO/WHO, 2001. Evaluation of health and nutritional properties of probiotics in food including powder milk with live lactic acid bacteria. Report of a Joint FAO/WHO Expert Consultation. Available at: http://www.fao.org/es/ESN/Probio/probio.htm

Fricourt BV, SF Barefoot, RF Testin, and SS Hayasaka, 1994. Detection and activity of plantaricin F an antibacterial substance from Lactobacillus plantarum BF001 isolated from processed channel catfish. J. Food Prot., 57: 698-702.

Fuller R, 1989. Probiotic in man and animals. J. Appl. Bacteriol., 66: 131-139.

Gardiner G, RP Ross, JK Collins, G Fitzgerald, and C Stanton, 1998. Development of a Probiotic Cheddar Cheese Containing Human-Derived Lactobacillus paracaseiStrains. Appl. Environ. Microbiol., 64: 21922199.

Gilliland SE and ML Speck, 1975. Inhibition of psychrotrophic bacteria by lactobacilli and pediococci in nonfermented refrigerated foods. J. Food Sci., 40: 903-905.

Guarner F and JR Malagelada, 2003. Gut flora in health and disease. The Lancet, 361: 512-519.

Hoque MZ, F Akter, KM Hossain, MSM Rahman, MM Billah and KMD Islam, 2010. Isolation, identification and analysis of probiotic properties of Lactobacillus spp. from selective regional yoghurts. World J. Dairy \& Food Sci., 5: 39-46.

Hoyos AB, 1999. Reduced incidence of necrotizing enterocolitis associated with enteral administration of Lactobacillus acidophilus and Bifidobacterium infantis to neonates in an intensive care unit. Int. J. Infect. Dis., 3: 197-202.

Hu S, L Wang and Z Jiang, 2017. Dietary additive probiotics modulation of the intestinal microbiota. Protein and peptide letters, 24: 382-387.

Islam KN, T Akbar, F Akther, and NN Islam, 2016. Characterization and confirmation of Lactobacillus spp. from selective regional yoghurts for probiotic and interference with pathogenic bacterial growth. Asian J. Biol. Sci., 9: 1-9.

Jayachitra $\mathbf{J}$ and $\mathrm{N}$ Ramanathan, 2012. Isolation of bacteriocin producing lactic acid bacteria from fish and its antimicrobial activity. Int J. Recent Sci. Res, 3: 581-584.

Joshi VK, S Sharma and NS Rana, 2006. Production, purification, stability and efficacy of bacteriocin from isolates of natural lactic acid fermentation of vegetables. J. Food Technol. Biotech., 44: 435-439. 
Li B, M Zhan, SE Evivie, D Jin, L Zhao, S Chowdhury and SK Sarker, 2018. Evaluating the safety of potemtial probiotic Enterococcus durans KLDS6. 0930 using whole genome sequencing and oral toxicity study. Front. Microbiol, 9: 1943.

Martínez-Cañavate A, S Sierra, F Lara-Villoslada, J Romero, J Maldonado, J Boza, and M Olivares, 2009. A probiotic dairy product containing L. gasseri CECT5714 and L. coryniformis CECT5711 induces immunological changes in children suffering from allergy. Pediatr. Allergy Immunol., 20: 592-600.

Nami Y, R Vaseghi Bakhshayesh, H Mohammadzadeh Jalaly, H Lotfi, S Eslami and MA Hejazi, 2019. Probiotic properties of Enterococcus isolated from artisanal dairy products. Front. Microbiol, 10: 300.

Nespolo CR and A Brandelli, 2010. Production of bacteriocin-like substances by lactic acid bacteria isolated from regional ovine cheese. Braz. J. Microbiol., 41: 1009-1018.

Nithya K, D Senbagam, B Senthilkumar, N Udhayashree and R Gurusamy, 2012. Characterization of bacteriocin producing lactic acid bacteria and its application as a food preservative. Afr. J. Microbiol. Res., 6: 1138-1146.

Pundir RK, S Rana, N Kashyap and A Kaur, 2013. Probiotic potential of lactic acid bacteria isolated from food samples: an in vitro study. J. Appl. Pharm. Sci., 3: 85.

Rahman MM, J Ferdouse, R Akter, MS Uddin, S Aktar, SC Paul, KI Anjum, M Mithun and MN Anwar, 2019. In vitro evaluation of probiotic and bacteriocinogenic potentiality of Lactobacillus plantarum and Lactobacillus delbrueckii isolated from vegetables in Chittagong region, Bangladesh. Malays. J. Microbiol, 15: 132-142.

Rahman MM, S Aktar, MO Faruk, MS Uddin, J Ferdouse and MN Anwar, 2018. Probiotic Potentiality of Lactobacillus coryniformis subsp. torquens MTi1 and Lactobacillus coryniformis MTi2 Isolated from Intestine of Nile Tilapia: An in vitro Evaluation. J. Pure Appl. Microbio., 12: 1037-1045.

Reid G, 2005. The importance of guidelines in the development and application of probiotics. Curr. Pharm. Des., 11: 11-16.

Sanders ME, 2003. Probiotics: considerations for human health. Nutrition reviews, 61: 91-99.

Tambekar DH and SA Bhutada, (2010). Studies on antimicrobial activity and characteristics of bacteriocins produced by Lactobacillus strains isolated from milk of domestic animals. The Internet Journal of Microbiology, 8: 1-6.

Ten Brink B, M Minekus, JMBM Van der Vossen and RJ Leer, 1994. Antimicrobial activity of lactobacilli: preliminary characterization and optimization of production of acidocin $\mathrm{B}$, a novel bacteriocin produced by Lactobacillus acidophilus M46. Journal of Applied Bacteriology, 77: 140-148.

Toral M, M Gómez-Guzmán, R Jiménez, M Romero, M Sánchez, M P Utrilla and J Duarte, 2014. The probiotic Lactobacillus coryniformis CECT5711 reduces the vascular pro-oxidant and pro-inflammatory status in obese mice. J. Clin. Sci., 127: 33-45.

Udhayashree N, D Senbagam, B Senthilkumar, K Nithya and R Gurusamy, 2012. Production of bacteriocin and their application in food products. Asian Pac. J. Trop. Bio., 2: S406-S410.

Yang E, L Fan, Y Jiang, C Doucette and S Fillmore, 2012. Antimicrobial activity of bacteriocin-producing lactic acid bacteria isolated from cheeses and yogurts. Amb Express, 2: 48. 